\title{
Absorptive Desulfurization of Model Biogas Stream Using Choline Chloride-Based Deep Eutectic Solvents
}

\author{
Edyta Słupek@ and Patrycja Makoś *๑థ \\ Department of Process Engineering and Chemical Technology, Faculty of Chemistry, \\ Gdansk University of Technology, G. Narutowicza St. 11/12, 80-233 Gdańsk, Poland; edyta.slupek@pg.edu.pl \\ * Correspondence: patrycja.makos@pg.edu.pl; Tel.: +48-508997100
}

Received: 6 February 2020; Accepted: 19 February 2020; Published: 21 February 2020

check for updates

\begin{abstract}
The paper presents a synthesis of deep eutectic solvents (DESs) based on choline chloride $(\mathrm{ChCl})$ as hydrogen bond acceptor and phenol ( $\mathrm{Ph}$ ), glycol ethylene (EG), and levulinic acid (Lev) as hydrogen bond donors in 1:2 molar ratio. DESs were successfully used as absorption solvents for removal of dimethyl disulfide (DMDS) from model biogas steam. Several parameters affecting the absorption capacity and absorption rate have been optimized including kinds of DES, temperature, the volume of absorbent, model biogas flow rate, and initial concentration of DMDS. Furthermore, reusability and regeneration of DESs by means of adsorption and nitrogen barbotage followed by the mechanism of absorptive desulfurization by means of density functional theory (DFT) as well as FT-IR analysis were investigated. Experimental results indicate that the most promising DES for biogas purification is $\mathrm{ChCl:Ph}$, due to high absorption capacity, relatively long absorption rate, and easy regeneration. The research on the absorption mechanism revealed that van der Waal interaction is the main driving force for DMDS removal from model biogas.
\end{abstract}

Keywords: deep eutectic solvents; absorption; biogas; dimethyl disulfide; green solvents; desulfurization

\section{Introduction}

Currently, more and more attention is paid to the production of alternative high-quality fuels, including bio-methane, bio-hydrogen, bio-ethanol, bio-butanol, etc. Biogas is a modern form of bioenergy, which can be obtained in the process of dark fermentation using waste products from various industries and agriculture (agri-food and animal waste) [1-3]. Biogas usually contains $30 \%-60 \%$ $v / v \mathrm{CH}_{4}, 15 \%-30 \% v / v \mathrm{CO}_{2}, 5 \%-20 \% v / v \mathrm{~N}_{2}, 1 \%-10 \% v / v \mathrm{O}_{2}$, and about $1 \%-2 \% v / v$ of other contaminants including $\mathrm{H}_{2} \mathrm{~S}, \mathrm{NH}_{3}$ and numerous of organic compounds [4-6]. Among the organic pollutants, volatile organosulfur compounds (VSCs) are one of the most important biogas impurities group. VSCs include sulfides, disulfides, thiophenes, and thiols, and the concentrations of them are strictly dependent on the raw material used for biogas production [7]. A typical range of VSCs concentration in biogas is shown in Table 1. 
Table 1. Range concentrations volatile organosulfur compounds (VSCs) in the biogas stream [7].

\begin{tabular}{cc}
\hline VSCs & Concentration $\left(\mathbf{m g} / \mathbf{N m}^{3}\right.$ biogas $)$ \\
\hline dimethyl sulfide & $1.25-2.76$ \\
carbon disulfide & $1.62-5.91$ \\
2-propanethiol & $0.50-1.19$ \\
1-propanethiol & $2.87-19.51$ \\
2-butanethiol & $0.79-4.65$ \\
thiophene & $0.16-1.16$ \\
methyl propyl sulfide & $0.35-1.76$ \\
dimethyl disulfide & $0.39-1.14$ \\
dipropyl disulfide & $0.76-3.16$ \\
\hline
\end{tabular}

Volatile organosulfur compounds are commonly found in many products and waste streams, causing technological and environmental problems $[8,9]$. VSCs are chemical compounds which are characterized by high toxicity, malodorousness, and high reactivity [10]. During biogas combustion, VSCs converted into toxic sulfur oxides (SOx) react with oxygen and water, forming sulfuric acid $\left(\mathrm{H}_{2} \mathrm{SO}_{4}\right)$ which corrode the surface in the combustion chamber. Therefore, biogas pre-treatment is necessary to protect engines that convert biogas into energy and in order to protect an environment [11,12].

Currently, there are many technologies to remove impurities from biogas, which are classified into three main categories: physical (e.g., absorption, adsorption, condensation), chemical (e.g., catalytic oxidation, thermal oxidation, ozonation), and biological (e.g., bio-scrubbers, bio-filters, activated sludge) [13-16]. Most of these methods are expensive and complicated, therefore, more and more attention is paid to optimize them in terms of low energy consumption and high efficiency [17-20]. Among the technologies, physical absorption is one of the most attractive methods due to its simplicity, economical, safe, and its potential high impurities removal efficiency from gas steams [21]. The choice of a suitable absorbent is the key to successful impurities removal. "Perfect" absorbent should be characterized by non-toxic character, high absorption capacity, high-boiling point, low vapor pressure, high diffusion coefficient, low prices, and safety [22]. Several solvents that may be useful for the removal of impurities include water, mineral oils, alcohols, ketones, and amines [23-25]. However, in accordance with the trends of "green chemistry", conventional solvents should be replaced by new generation absorbents. Until recently, studies have focused on ionic liquids (ILs) as absorbents due to their unique properties [26]. However, the problems with their toxicity, stability, biodegradability, and expensive synthesis make them less than ideal solvents. Alternatives to ILs are deep eutectic solvents (DESs), which have similar physico-chemical properties. DESs are a mixture consisting mainly of two or three non-toxic and biodegradable compounds that are capable of forming eutectic liquids, based on the specific interaction between hydrogen bond donor (HBD) and hydrogen bond acceptor (HBA) [27,28]. Until now, DESs have been widely used for desulfurization of fuels [9], biomass pre-treatment [29], water and air purification [30,31], in catalysis [32], and analytical chemistry [27,33,34]. Till now, no studies have been in the literature published regarding the use of DESs as absorbents to remove volatile organosulfur compounds from the biogas stream. The studies presented in the literature are limited to the removal of inorganic compounds, i.e., $\mathrm{H}_{2} \mathrm{O}, \mathrm{CO}_{2}, \mathrm{H}_{2} \mathrm{~S}$, and $\mathrm{NH}_{3}$ from gaseous phases [35-37]. Only a few works refer to their use to remove volatile organic compounds from the gas phase [38,39].

The paper describes the synthesis of DES composed of choline chloride (HBA) and phenol, ethylene glycol, levulinic acid (HBD) in a 1:2 molar ratio. The absorptive desulfurization was optimized on selection terms of DES type, temperature, absorbent volume, initial concentration of dimethyl disulfide (DMDS), and model biogas flow rate. Two most popular desorption methods including adsorption and nitrogen barbotage were investigated. For the better understand the mechanism of DMDS removal, FT-IR and density functional analysis were employed. 


\section{Materials and Methods}

\subsection{Reagends}

The research was used reagents choline chloride $(\mathrm{ChCl})$ (purity $\geq 99 \%$ ), diethylene glycol (EG) (purity $\geq 95 \%$ ), levulinic acid (Lev) (purity $\geq 98 \%$ ), phenol (purity $\geq 99 \%$ ), dimethyl disulfide (purity $\geq 98 \%$ ), silica gel (SG) (grain diameter $\mathrm{dp}=40 \mu \mathrm{m}$ ), active carbon (AC) (grain diameter $\mathrm{dp}=0.3-0.5 \mathrm{~mm}$ ), and aluminum oxide (III) $(\mathrm{AO})$ (grain diameter $\mathrm{dp}=40 \mu \mathrm{m}$ ) were purchased from Sigma-Aldrich (USA). Compressed gases such as nitrogen (purity N 5,5), air (purity N 5.0) generated by a DK50 compressor with a membrane dryer (Ekkom, Poland), and hydrogen (purity N 5.5) generated by a 9400 Hydrogen Generator (Packard, USA) were used for the preparation of model biogas, regeneration process, and chromatographic analysis.

\subsection{Apparatures}

Gas chromatograph Autosystem XL equipped with flame ionization detector (GC-FID) (PerkinElmer, USA), HP-5 $(30 \mathrm{~m} \times 0.25 \mathrm{~mm} \times 0.25 \mu \mathrm{m})$ capillary column (Agilent Technologies, USA), TurboChrom 6.1 software (PerkinElmer, USA), and FT-IR Bruker Tensor 27 spectrometer (Bruker, USA) with an ATR accessory and OPUS software (Bruker, USA) were used.

\subsection{Procedures}

\subsubsection{Preparation of DES}

DESs were synthesized by mixing $\mathrm{ChCl}(\mathrm{HBA})$ with $\mathrm{Ph}, \mathrm{EG}$, and $\mathrm{Lev}(\mathrm{HBD})$ in a 1:2 molar ratio. The mixtures were stirred magnetically at $65{ }^{\circ} \mathrm{C}$ until homogeneous liquids were obtained. The liquids were then left to cool spontaneously to room temperature. The physico-chemical properties of the synthesized DES were presented in Table 2.

Table 2. Selected physico-chemical properties of deep eutectic solvents (DESs) reported in the literature.

\begin{tabular}{ccccccc}
\hline HBA & HBD & $\begin{array}{c}\text { HBA:HBD } \\
\text { Molar Ratio }\end{array}$ & $\begin{array}{c}\text { Melting Points } \\
\left({ }^{\circ} \mathbf{C}\right)\end{array}$ & $\begin{array}{c}\text { Density } \\
\left(\mathbf{g} / \mathbf{c m}^{\mathbf{1}}\right)\left(\mathbf{2 5}{ }^{\circ} \mathbf{C}\right)\end{array}$ & $\begin{array}{c}\text { Viscosity } \\
(\mathbf{c P})\left(\mathbf{2 5}{ }^{\circ} \mathbf{C}\right)\end{array}$ & Ref. \\
\hline \multirow{3}{*}{$\mathrm{ChCl}$} & Ph & \multirow{2}{*}{$1: 2$} & Liquid at RT & 1.10 & 14 & {$[40]$} \\
& EG & & -68.9 & 1.12 & 32 & {$[41]$} \\
& \multicolumn{5}{c}{${ }^{*}$ RT-room temperature. }
\end{tabular}

\subsubsection{Absorption Process}

The absorption process was prepared by means of the barbotage phenomena. Nitrogen (model biogas stream) was passed through a 20-mL vial containing $5 \mathrm{~mL}$ of DMDS. The created mixture (nitrogen-DMDS) was diluted with a nitrogen stream to $1.0 \mathrm{mg} / \mathrm{Nm}^{3}$ (DMDS) concentration. The model biogas stream containing DMDS was passed through an absorption column (total volume $60 \mathrm{~mL}$ ) containing $50 \mathrm{~mL}$ of DES. The total flow of gaseous DMDS and nitrogen was kept constant at $50 \mathrm{~mL} / \mathrm{min}$. The concentration of DMDS was monitored at the inlet and outlet of the barbotage column using GC-FID. The processes were carried out for $1200 \mathrm{~min}$. The absorptivity (A) of DMDS in the DES was calculated using Equation (1):

$$
A=\frac{C_{\text {in }}-C_{\text {out }}}{C_{\text {in }}}
$$

where $C_{i n}$-initial DMDS concentration (ppm $\left.v / v\right)$,

$C_{o u t}$-DMDS concentration after absorption process (ppm $v / v$ ). 


\subsubsection{Regeneration of DESs}

After the absorption process, DESs were regenerated using two popular methods, including nitrogen barbotage and adsorption. Nitrogen barbotage was carried on as follows: $4 \mathrm{~mL}$ of DES was barbotaged using nitrogen flow $50 \mathrm{~mL} / \mathrm{min}$ for 2.5 or $5 \mathrm{~h}$. Three types of adsorbents, i.e., AC, SG, and $\mathrm{AO}$ were used in the second type of regeneration process. All adsorbents were activated in a laboratory dryer at $120^{\circ} \mathrm{C}$ for $2 \mathrm{~h}$. The $4 \mathrm{~mL}$ of DES containing DMDS was mixed with $160 \mathrm{mg}$ and $420 \mathrm{mg}$ adsorbents in a vial. The vials were maintained in a laboratory shaker at $25^{\circ} \mathrm{C}$ for $30 \mathrm{~min}$, subsequently centrifuged for $5 \mathrm{~min}$ at $7000 \mathrm{rpm}$, and filtered through a $0.45 \mu \mathrm{m}$ cellulose filter. The concentration of DMDS in DES (before and after regeneration) was controlled using static headspace coupled to gas chromatography (SHS-GC).

\subsubsection{Chromatographic Analysis}

GC temperature program was $120^{\circ} \mathrm{C}$; injection port temperature was $300^{\circ} \mathrm{C}$ carrier gas-nitrogen ( $2 \mathrm{~mL} / \mathrm{min})$; injection mode: split 20:1; detector temperature was $300^{\circ} \mathrm{C}$; detector gases flow rates were hydrogen $40 \mathrm{~mL} / \mathrm{min}$ and air $400 \mathrm{~mL} / \mathrm{min}$. DESs $(2 \mathrm{~mL})$ after regeneration were thermostated at $80^{\circ} \mathrm{C}$ for $50 \mathrm{~min}$. Then, $0.1 \mathrm{~mL}$ of gas phase was introduced into the GC injector. In order to monitor DMDS concentrations during the absorption process, $0.5 \mathrm{~mL}$ of model biogas was analyzed.

\subsubsection{FT-IR Analysis}

The following working parameters of FT-IR analysis were used: spectral range: $4000-550 \mathrm{~cm}^{-1}$; number of background scans: 256; number of sample scans: 256; resolution: $4 \mathrm{~cm}^{-1}$; slit width: $0.5 \mathrm{~cm}$.

\subsubsection{Theoretical Studies}

The molecular structures and interactions between DES and DMDS were optimized using the B3LYP/6-311++ $G^{* *}$ level of theory with the dispersion corrected computational model using Orca 4.1.1 software package. All configurations were optimized for local minima using frequency calculations. The interaction energy for the gas phase between the DES and DMDS was calculated according to the following expression (Equation (2)):

$$
\Delta E=E_{D E S-H M D S}-\left(E_{D E S}-E_{H M D S}\right)
$$

where $E_{D E S-H M D S}$ - total energy of complex DES-DMDS (kcal/mol);

$E_{D E S}$-individual energy of DES ( $\left.\mathrm{kcal} / \mathrm{mol}\right)$;

$E_{H M D S}$-individual energy of HMDS ( $\left.\mathrm{kcal} / \mathrm{mol}\right)$.

The counterpoise method has also been implemented to estimate the effects of the basis set superposition error (BSSE) on the interaction energy, based on previous studies [43]. Electrostatic potential analysis (ESP) and reduced density gradient analysis (RGD) were performed to the visual interpret the interaction nature in the DES-DMDS complex. Both RDG and ESP analysis were performed using Multiwfn software [44-46]. In order to the graphical presentation of the results, the Visual Molecular Dynamics 1.9.3, the software was used.

\section{Results and Discussion}

\subsection{Optimization of Absorption Conditions}

Optimization of absorption conditions using deep eutectic solvents was carried out for DMDS as the main representative of volatile organosulfur compounds commonly found in real biogas streams [7,47-50]. The process was optimized in terms of DES type, temperature, the volume of DES, model biogas flow, and initial concentration of DMDS. 


\subsubsection{Kind of DES}

The selection of the absorption solvent is particularly important in the absorptive desulfurization process. Three types of DES were tested, including $\mathrm{ChCl}: \mathrm{Ph}, \mathrm{ChCl}: \mathrm{Lev}$, and $\mathrm{ChCl}: \mathrm{EG}$ in a 1:2 molar ratio (Figure 1). In the experiment, the following pre-selected absorption conditions were used: $50 \mathrm{~mL}$ of DES; initial concentration of DMDS $1 \mathrm{mg} / \mathrm{Nm}^{3}, 2{ }^{\circ} \mathrm{C}$ temperature; model biogas flow rate $50 \mathrm{~mL} / \mathrm{min}$. Among the investigated DESs, $\mathrm{ChCl}: \mathrm{Ph}$ shows the best absorption efficiency. After $800 \mathrm{~min}$, the absorptivity value for $\mathrm{ChCl}: \mathrm{Ph}$ was below 0.3 and then increased rapidly over the next $300 \mathrm{~min}$, which indicates DES saturation. The saturation time of the other two DES was 600 and $800 \mathrm{~min}$ for ChCl:EG and ChCl:Lev, respectively. It can be noticed that the best result was obtained for DES which has the lowest viscosity value. As the viscosity increased, both the absorption capacity and absorption rate decreased. In DES with higher viscosity, the mass transfer is hindered, therefore it is preferable to use solvents with the lowest viscosity.

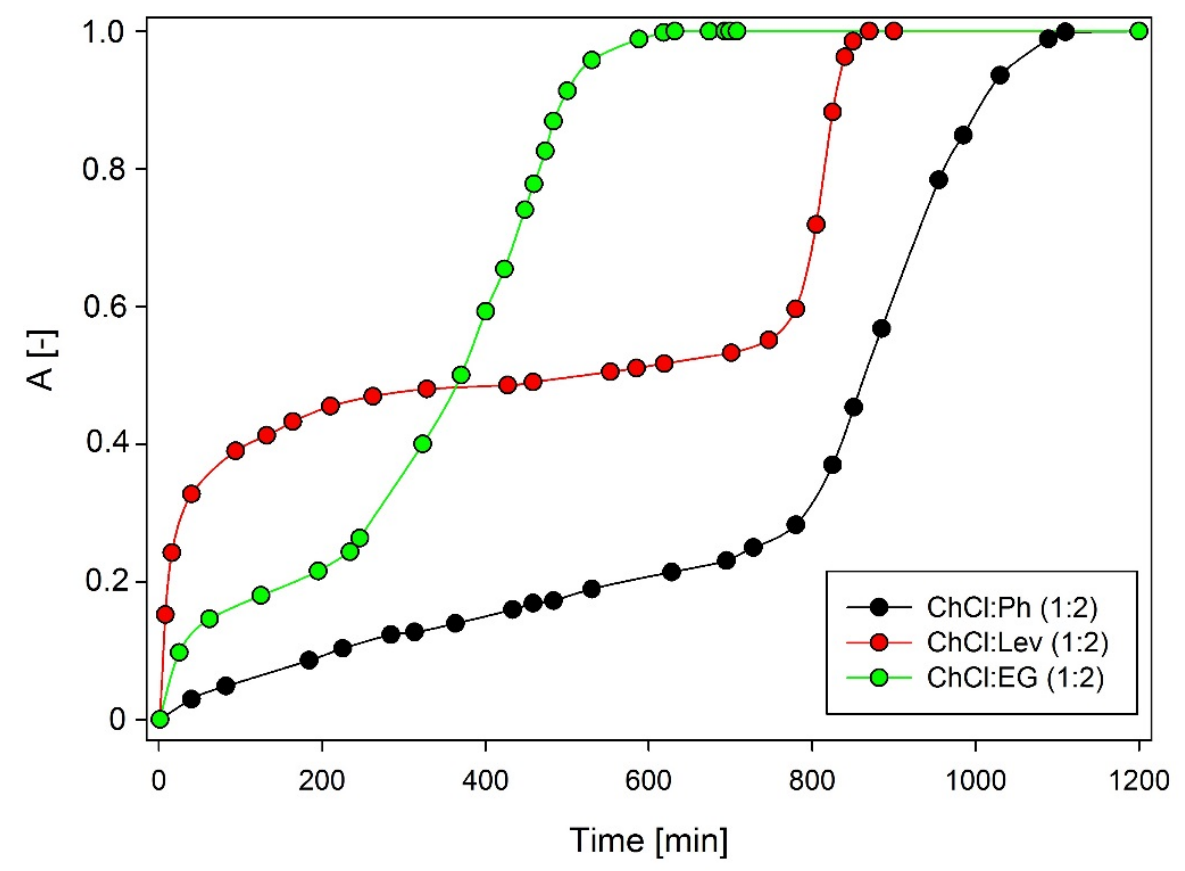

Figure 1. Dimethyl disulfide (DMDS) absorption curves using DES under optimum conditions.

It is worth noting that the viscosity of the DES increases when the amounts of hydroxyl groups in HBD increases. The existence of extra hydroxyl groups creates a more extensive hydrogen bond network which results in lower mobility of free species within the DES [28]. However, many other factors (except viscosity) also influence the DMDS removal efficiency, therefore in Section 3.2., the mechanism of absorptive desulfurization of model biogas was explained.

\subsubsection{Volume of DES}

In the studies, three-volume of DES in the range of $15-50 \mathrm{~mL} / \mathrm{min}$ were investigated (Figure 2a). In the studies, other operating parameters, i.e., inlet concentration DMDS $1 \mathrm{mg} / \mathrm{Nm}^{3}$, nitrogen flow rate $50 \mathrm{~mL} / \mathrm{min}$, and the temperature of process $25^{\circ} \mathrm{C}$, were constant. The results showed that with the increase in DES volume, the absorption efficiency increased significantly from $695 \mathrm{~min}$ to $1200 \mathrm{~min}$. This is due to the fact that as the volume of the absorbent increases, the contact time between the gas phase and the liquid increases, due to which the saturation time is longer. Similar results were obtained in the work [51,52]. 


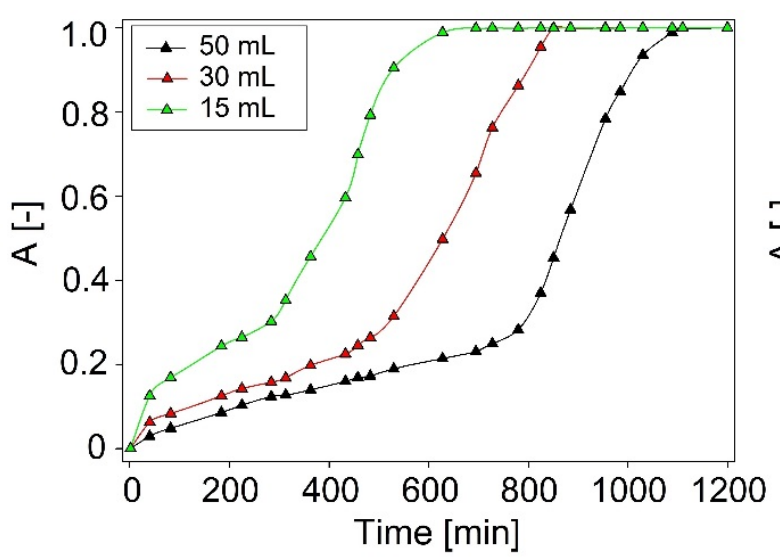

(a)

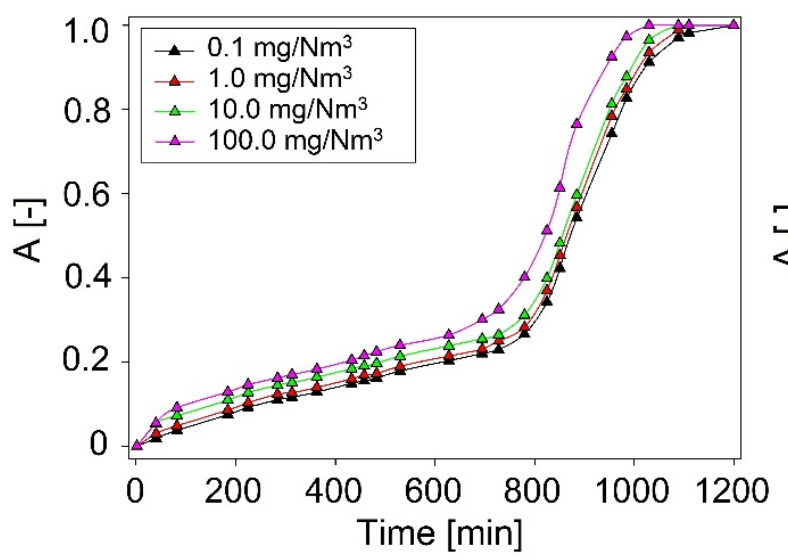

(c)

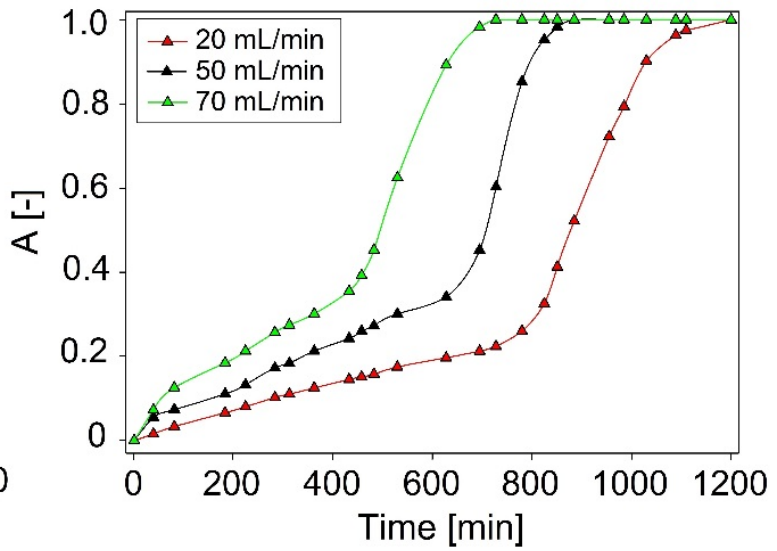

(b)

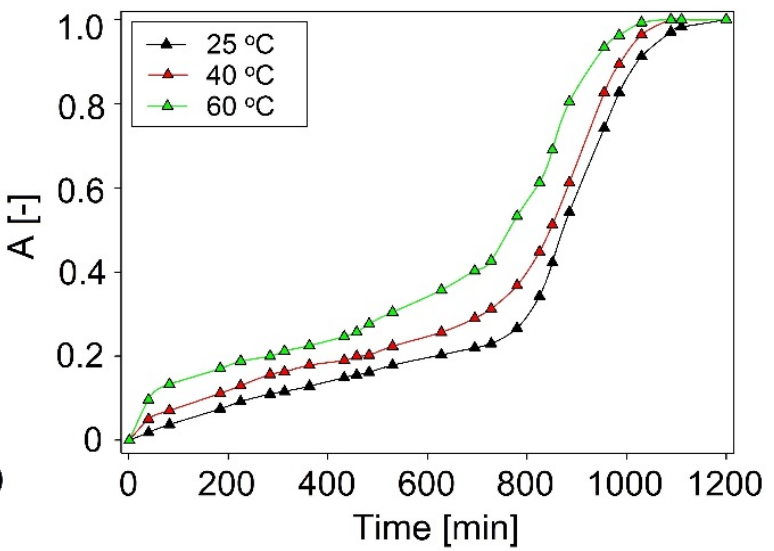

(d)

Figure 2. Experimental breakthrough curves of DMDS absorption with $\mathrm{ChCl:Ph}$ at different: (a) volume of DES; (b) biogas flow rate; (c) initial concentration of DMDS; (d) temperature.

\subsubsection{Model Biogas Flow Rate}

The next studied parameter was model biogas flow rate in the range of $20-70 \mathrm{~mL} / \mathrm{min}$ (Figure $2 \mathrm{~b}$ ). From an industrial point of view, the flow rate of biogas should be as high as possible. The results indicate that the flow rate has a large impact on the overall DMDS capture process. As the flow rate increases from 20 to $70 \mathrm{~mL} / \mathrm{min}$, the DES saturation time is reduced from 1200 to $729 \mathrm{~min}$. Similar results were obtained in the research [51-53]. This is due to the fact that as the flow velocity increases, the contact time of the polluted gas stream with the absorbent is reduced, which adversely affects the DMDS absorption process. However, only a slight change in saturation time is observed between the flow of 20 and $50 \mathrm{~mL} / \mathrm{min}$. Therefore, a $50 \mathrm{~mL} / \mathrm{min}$ model biogas flow rate was considered as optimum value.

\subsubsection{Initial Concentration of DMDS}

In the studies, the initial concentration of DMDS in the range of $0.1-100 \mathrm{mg} / \mathrm{Nm}^{3}$ was investigated (Figure 2c). The results indicate that the DMDS absorption efficiency remains fairly stable despite an increase in DMDS inlet concentration. This valuable result shows the ability of $\mathrm{ChCl}: \mathrm{Ph}$ to the removal of DMDS in varying concentrations from real biogas steam which makes it desirable from an industrial point of view. Similar results were obtained in the work [54].

\subsubsection{Temperature}

Three temperature values, i.e., 25,40 , and $60^{\circ} \mathrm{C}$, were chosen to assess the influence of temperature on DMDS absorption behavior (Figure 2d). Theoretically, an increase in temperature affect the decreases 
in DES viscosity and hence gas transfer rate are improved. The absorption curve reveals that by increasing DES temperature, the solubility of DMDS decreases. The decrease in solubility can be explained by the fact that the gas absorption process is normally exothermic. Therefore, the preferred temperature using DES is $25^{\circ} \mathrm{C}$, because in using this temperature the longest effective purification time for the biogas stream is achieved, lasting up to $1200 \mathrm{~min}$. When the temperature is increased to $60^{\circ} \mathrm{C}$, the absorption time is reduced to $1010 \mathrm{~min}$. Consequently, the absorption process can be performed at room temperature with minimal energy consumption. Similar results were obtained at work [55].

\subsection{Mechanism of Absorption}

\subsubsection{FT-IR analysis}

The experimental research on the mechanism of the absorption process was performed by FT-IR analysis. The spectra of pure DESs were compared with pure DMDS, and DES-DMDS complex spectra (Figure 3a-c). All characteristic bands that can be attributed to DMDS $\left(2909.32 \mathrm{~cm}^{-1}-\delta \mathrm{s}(\mathrm{CH})\right.$ stretch, $1411.73 \mathrm{~cm}^{-1}$ - $\delta$ as $\left(\mathrm{CH}_{3}\right)$ def., $1302.68 \mathrm{~cm}^{-1}$ - $\delta \mathrm{s}\left(\mathrm{CH}_{3}\right)$ def., $692.82 \mathrm{~cm}^{-1}$-C-S stretch, $540.96 \mathrm{~cm}^{-1}$-S-S stretch) are visible in the ChCl:Ph-DMDS spectrum [56], which indicates the creation of the DES-DMDS complex (Figure 3a). Theoretically, in the absorptive DMDS removal process, both sulfur atoms can act as a donor in $\mathrm{S}-\mathrm{H} \cdots \pi$ and as an acceptor in $\mathrm{O}-\mathrm{H} \cdots \mathrm{S}$ and $\mathrm{C}-\mathrm{H} \cdots \mathrm{S}$ interactions [57-59]. However, on the FT-IR spectra, there are no shifts corresponding to this type of interaction. Therefore, other interactions must play a key role in the DMDS absorption process. Similar results were also obtained for ChCl:Lev (Figure 3b) and ChCl:EG (Figure 3c).

\subsubsection{Molecular Modeling}

In order to better understand the mechanisms of DMDS removal from the gas phase using DES, the density functional theory (DFT) was applied. For this purpose, the most probable and stable configurations in the gas phase of $\mathrm{ChCl}$ :Ph-DMDS, ChCl:Lev-DMDS, and ChCl:EG-DMDS was geometry optimized at the B3LYP/6-311++ $G^{* *}$ level of theory (Figure 4). The results indicate that in all complex, nonbonded interaction exists between choline and chloride atom $(\mathrm{O}-\mathrm{H} \cdots \mathrm{Cl})$, which can be identified as strong hydrogen bond because of short distance (below $2.5 \AA$ ) [60]. Hydrogen bonds also occur between the $\mathrm{Cl}$ atom and two phenol molecules such as $\mathrm{Cl} \cdots \mathrm{H}-\mathrm{O}(2.32 \AA)$ and $\mathrm{Cl} \cdots \mathrm{H}-\mathrm{O}(2.44 \AA)$ in the $\mathrm{ChCl}: \mathrm{Ph}-\mathrm{DMDS}$ complex, between $\mathrm{Cl}$ atom and carboxylic group of levulinic acid $(\mathrm{Cl} \cdots \mathrm{H}-\mathrm{OOC}$ $2.07 \AA$ ), carboxylic groups of two levulinic acid molecules ( $\mathrm{OH} \cdots \mathrm{OH} 1.88 \AA$ ) in ChCl:Lev-DMDS, and between the $\mathrm{Cl}$ atom and hydroxyl group of one EG molecule ( $\mathrm{Cl} \cdots \mathrm{H}-\mathrm{O} 2.13 \AA$ ) as well as between

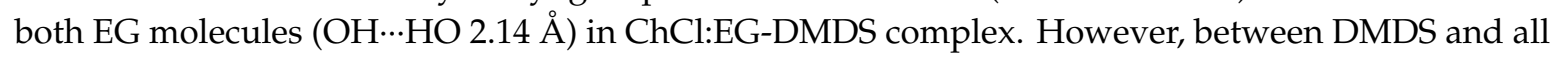
DES, there are no hydrogen bonds and only weak electrostatic bonds occur.

Electrostatic potential analysis (ESP) was used for visualization of total charge distribution and relative polarity of the studied DMDS structure and DESs-DMDS complexes. The ESP of DMDS, $\mathrm{ChCl}: \mathrm{Ph}-\mathrm{DMDS}, \mathrm{ChCl}: L e v-D M D S$, and $\mathrm{ChCl}$ :EG-DMDS are mapped onto their electron densities in Figure 5. The results indicate that the electropositive areas are around the hydrogen atoms whereas the electronegative area is around sulfur atoms, in the DMDS structure. In the ChCl:Ph-DMDS complex, a large electropositive area is around the nitrogen atom and electronegative areas are around $\mathrm{Cl}, \mathrm{O}$, and $\mathrm{S}$ atoms. During the absorption process, the electronegative region located around sulfur atoms in the DMDS molecule interacts with the electropositive area located around the nitrogen atom in the $\mathrm{ChCl}: \mathrm{Ph}$ molecule. These interactions provide efficient DMDS removal from the model biogas. On the other hand, it can be concluded that HBA in the DES molecule has the greatest impact on the purification process. This phenomenon will be investigated in subsequent works. Similar results can be found in ChCl:Lev-DMDS and ChCl:EG-DMDS complex. 


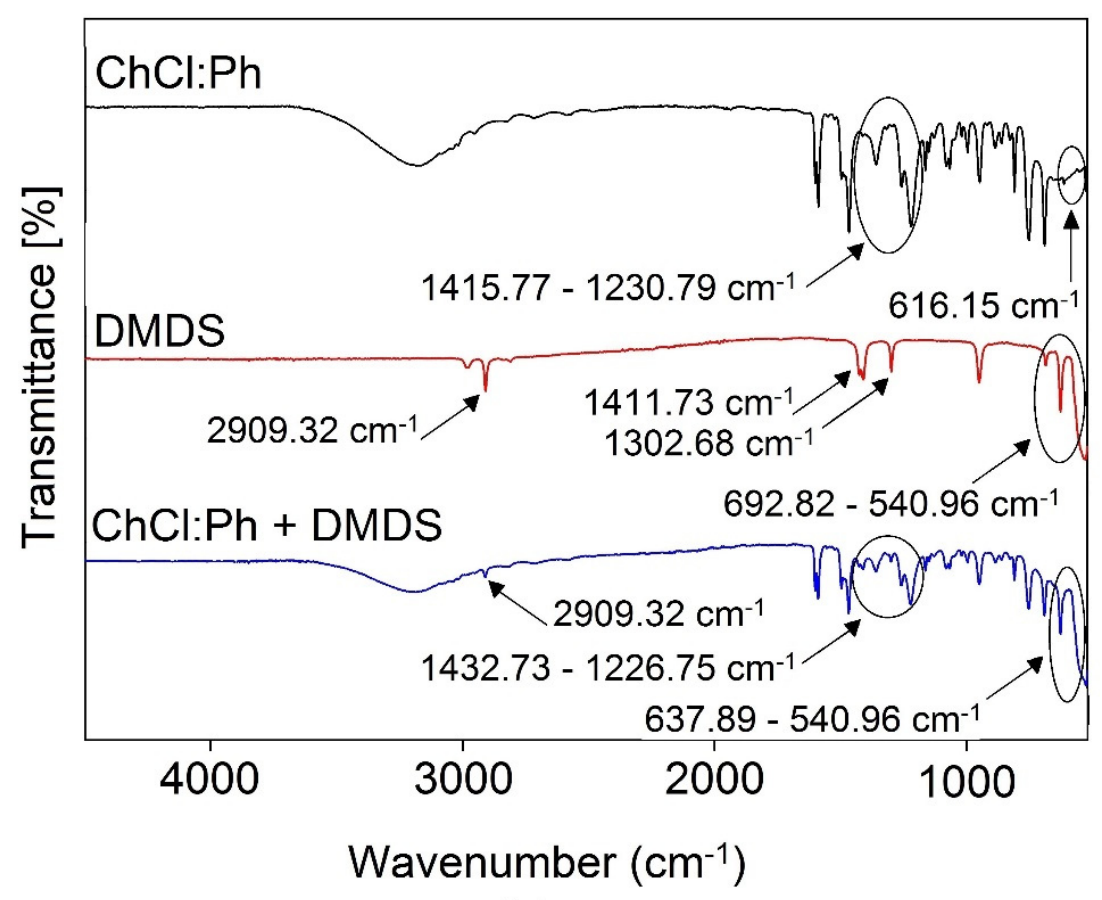

(a)

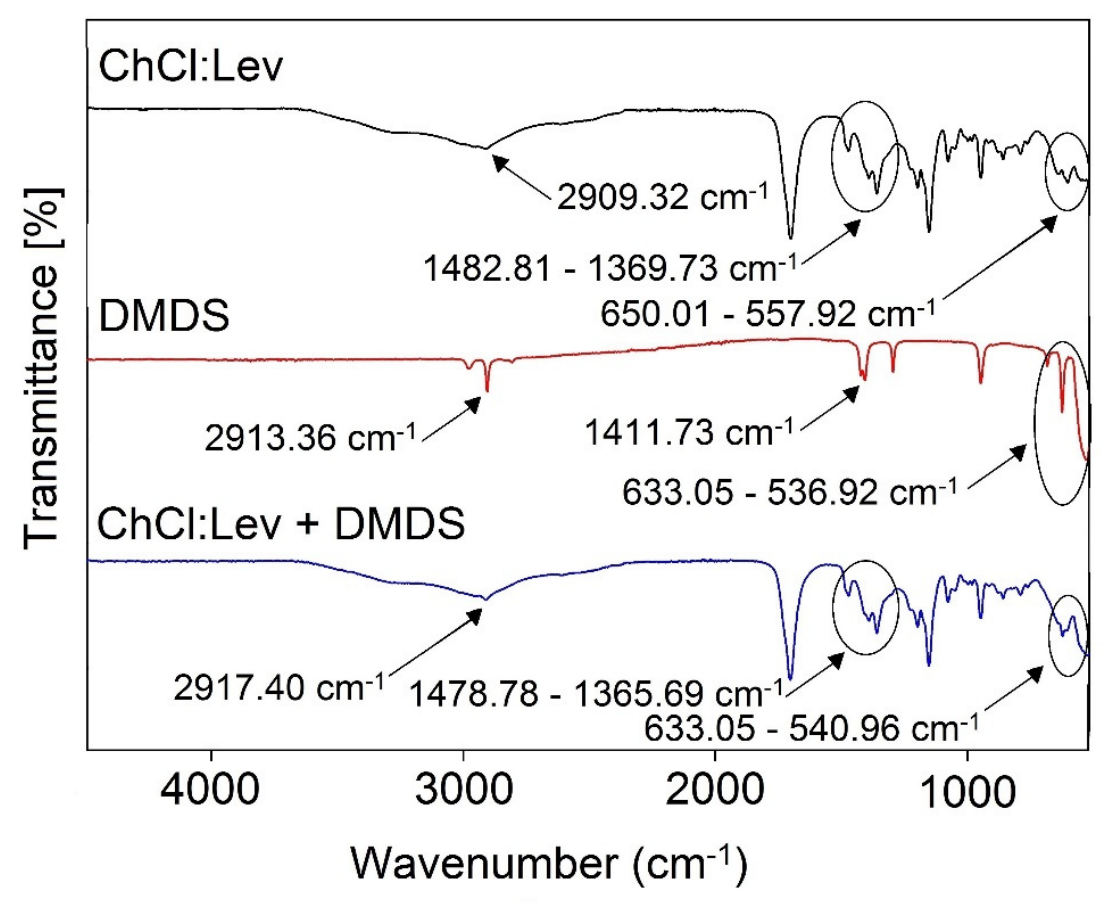

(b)

Figure 3. Cont. 


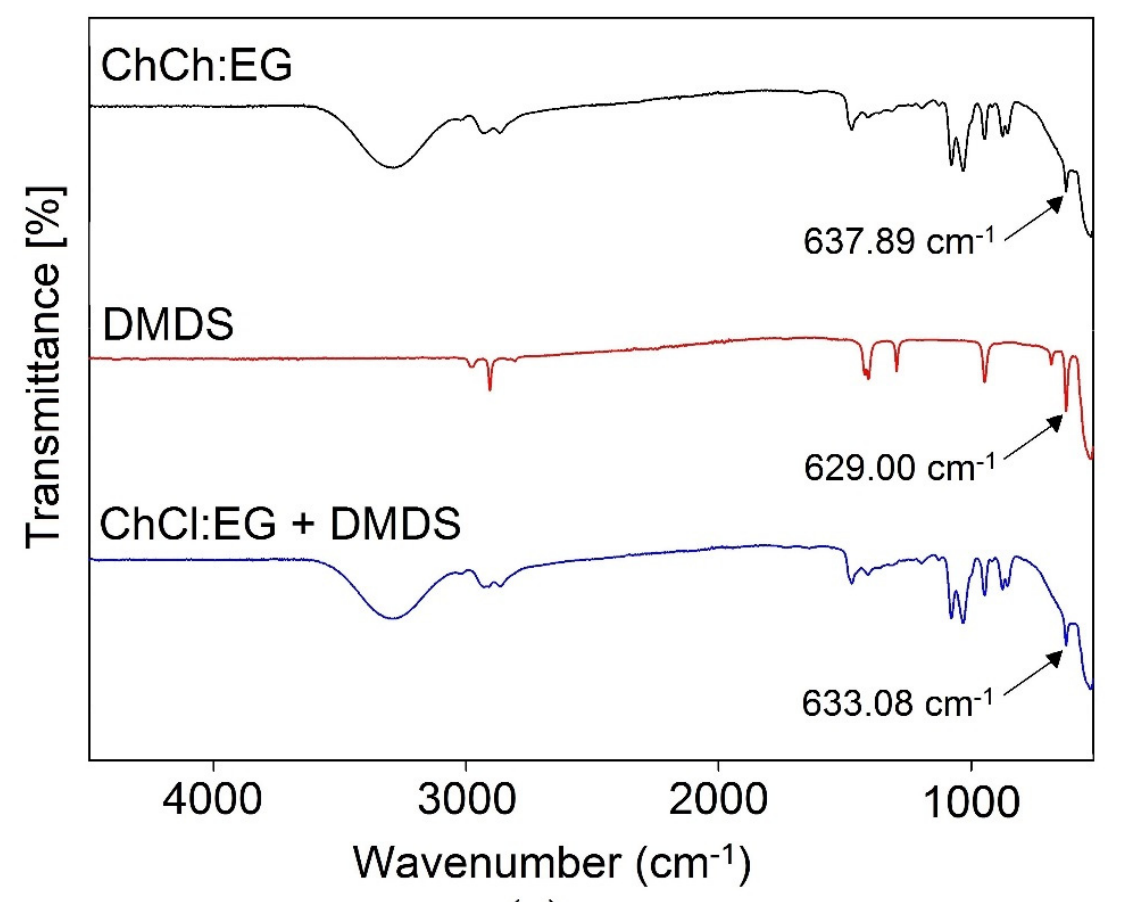

(c)

Figure 3. FT-IR spectra of: (a) pure $\mathrm{ChCl}: \mathrm{Ph}$, pure DMDS, and DES after the DMDS absorption process; (b) ChCl:Lev, pure DMDS, and DES after the DMDS absorption process; (c) pure ChCl:EG, pure DMDS, and DES after the DMDS absorption process.

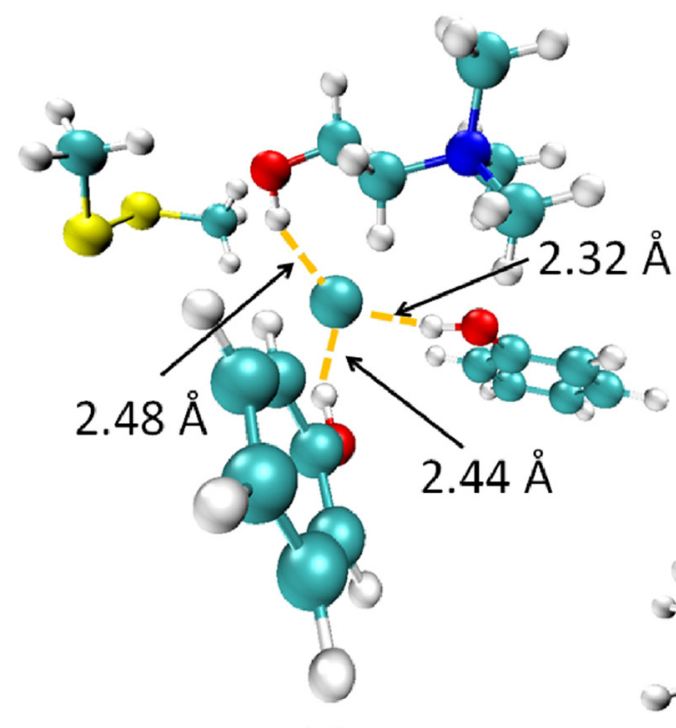

(a)

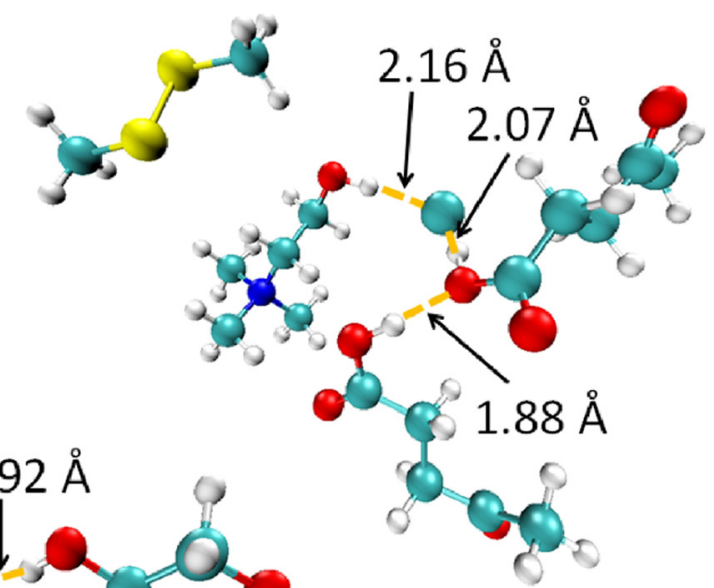

(b)

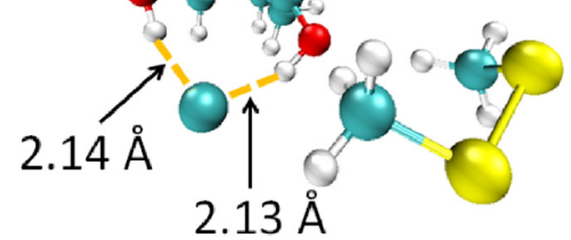

(c)

Figure 4. Optimized configurations of (a) ChCl:Ph-DMDS; (b) ChCl:Lev-DMDS; (c) ChCl:EG-DMDS. Carbon and chlorine atoms are displayed in light blue, nitrogen atoms are in dark blue, oxygen atoms are in red, sulfur atoms are in yellow, and hydrogen atoms are in white. 


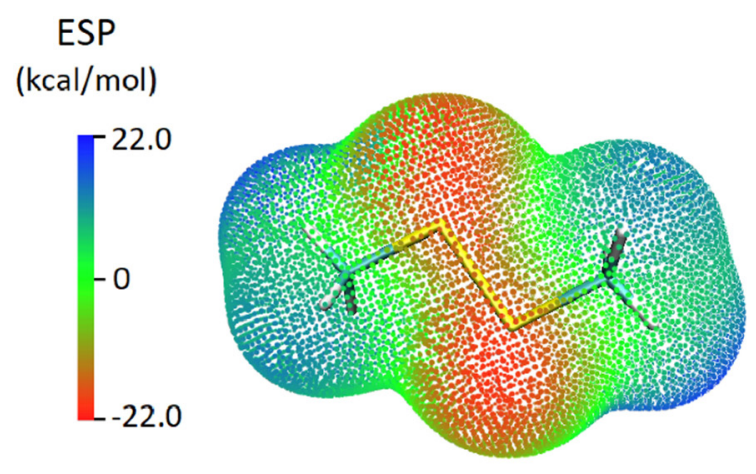

(a)

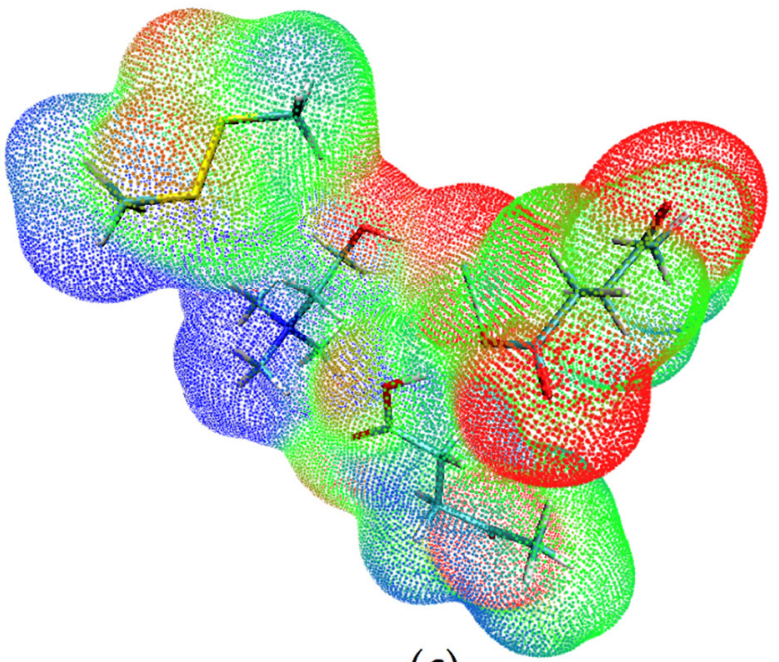

(c)

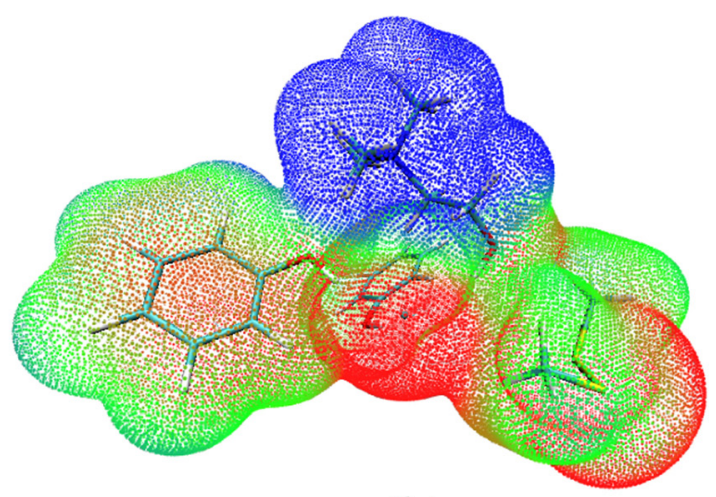

(b)

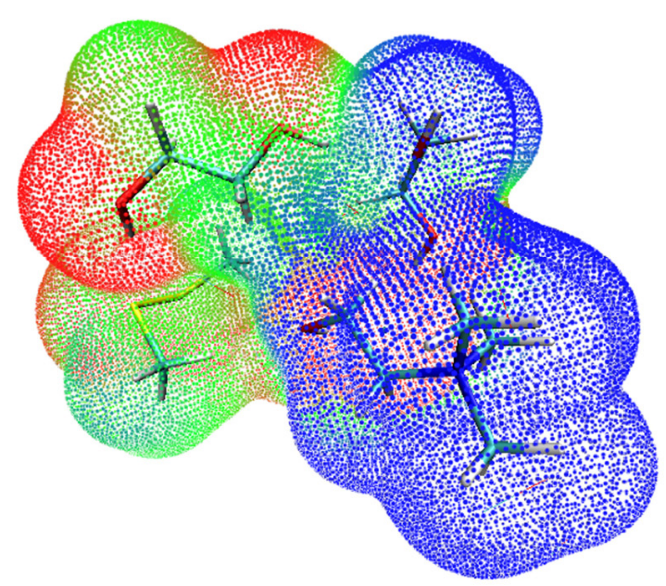

(d)

Figure 5. Electrostatic potential mapped on electron total density with an isovalue 0.001 for (a) DMDS; (b) ChCl:Ph-DMDS; (c) ChCl:Lev-DMDS; (d) ChCl:EG-DMDS. Blue color represents positive charges, red color represents negative charges.

The reduced density gradient (RDG) is a beneficial approach to distinguish and visualize various types of noncovalent interactions in real space. In the studies, the RDG analysis was used to visualized weak noncovalent interactions (i.e., hydrogen bond, van der Waals interaction, and repulsive effect), by plotting the RDG versus the electron density multiplied by the sign of the second Hessian eigenvalue, based on previous studies [44]. In Figure $6 \mathrm{~b}, \mathrm{~d}, \mathrm{f}$, the green surfaces indicate van der Waals interaction, red surfaces indicate strong repulsion, and blue surfaces indicate an H-bond. The obtained data show that the three hydrogen bonds, as well as the van der Waals interaction, were formed between HBA and HBDs in all studied DES, which correspond to a large, negative $\operatorname{sign}(\lambda 2) \rho$ value (from -0.04 to $-0.02 \mathrm{au}$ ) and $0.01 \mathrm{au}<\operatorname{sign}(\lambda 2) \rho<0.01 \mathrm{au}$, respectively, in 2D diagrams (Figure 6a,c,e). Furthermore, in ChCl:Ph-DMDS, strong repulsive bonds occur $(\operatorname{sign}(\lambda 2) \rho=0.02 \mathrm{au})$, due to the presence of an aromatic ring in the phenol molecule. In all the studied complexes, between DES and DMDS, only a van der Waals interaction occur. The surfaces of the van der Waals interaction increase following the order of ChCl:EG-DMDS < ChCl:Lev-DMDS < ChCl:Ph-DMDS. This indicates that the main driving force affecting DMDS removal from model biogas is the van der Waals interactions. 


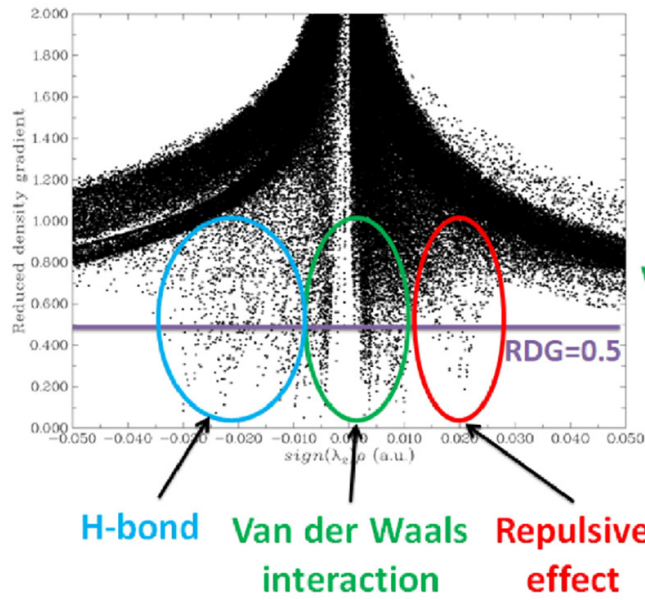

(a)

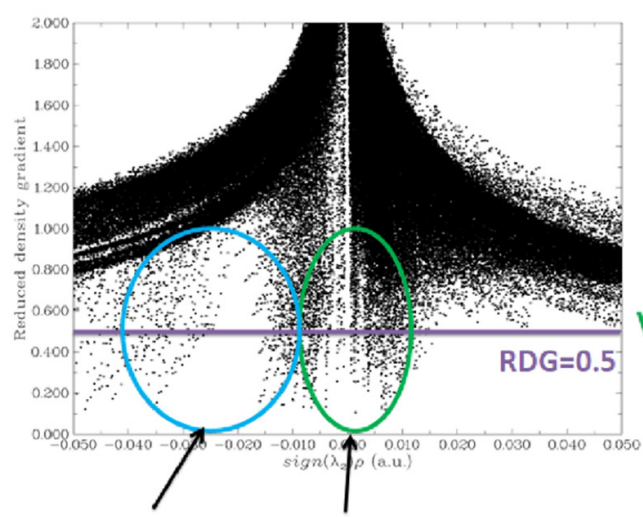

H-bond Van der Waals

interaction

(c)

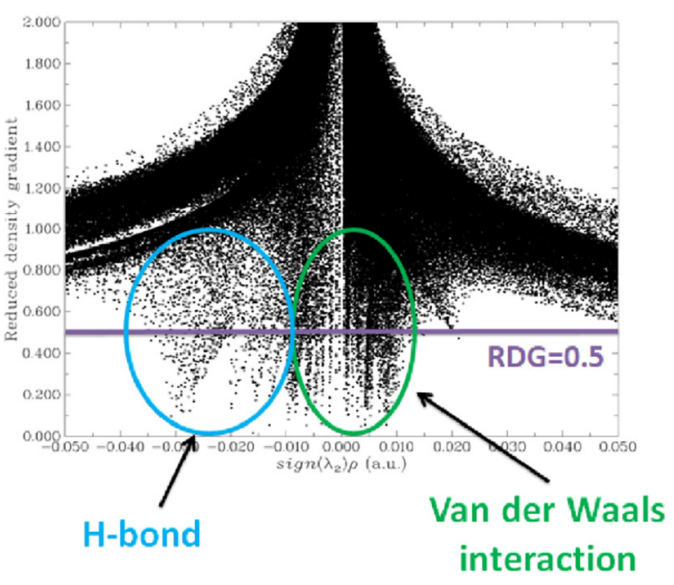

(e)

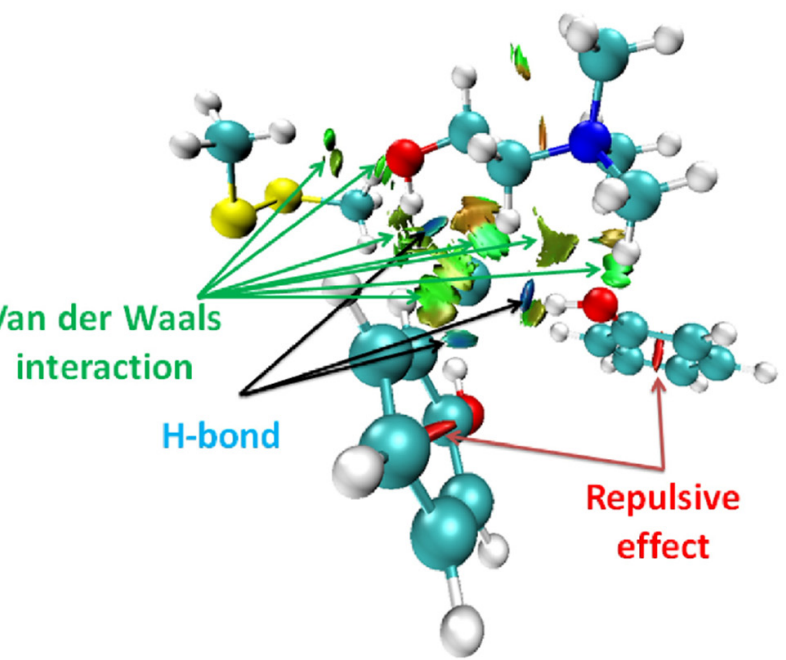

(b)

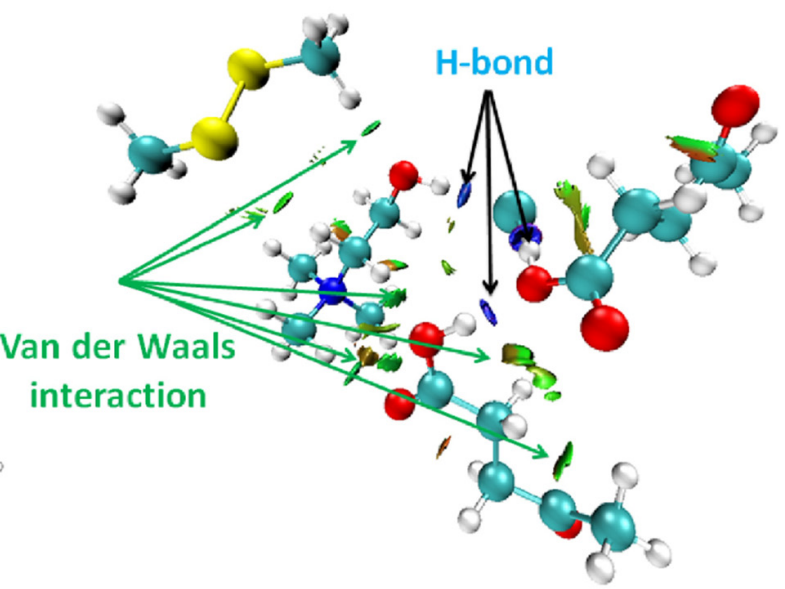

(d)

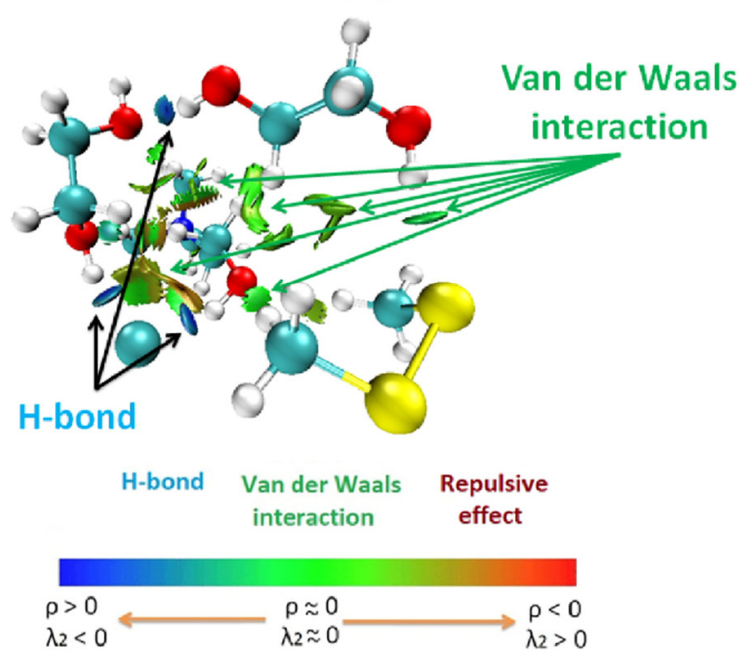

(f)

Figure 6. RDG isosurfaces ( $\mathrm{s}=0.5$ a.u.) and 2D diagrams of electron density and its reduced density gradient for (a,b) ChCl:Ph-DMDS; (c,d) ChCl:Lev-DMDS; (e,f) ChCl:EG-DMDS. 
The calculated interaction energy in the gas phase between DES and DMDS were $-10.8,-3.7$, and -9.6 kcal/mol for ChCl:Ph-DMDS, ChCl:Lev-DMDS, and ChCl:EG-DMDS, respectively. The lower interaction energy values stand for stronger interaction between DES and DMDS. The obtained data followed a similar trend to the experimental data: ChCl:Ph-DMDS $<$ ChCl:EG-DMDS < ChCl:Lev-DMDS.

\subsection{Regeneration and Reusability of DES}

From an industrial point of view, the regeneration of DES is an essential and significant factor because it has a great impact on the operating cost. Therefore, regeneration of DES was carried on through one of the best-known regenerative methods, i.e., nitrogen barbotage (NG, which was carried for 2.5 and $5 \mathrm{~h}$ ) and the adsorption process (with different types and amounts of adsorbents). In the adsorption process, three types of adsorbents were tested including SG, AC, and AO, in the amounts of 160 and $420 \mathrm{mg}$, which were added to $4 \mathrm{~mL}$ of each DES and shaken for $30 \mathrm{~min}$. The results indicate that the nitrogen barboage is the most efficient desorption method. Desorption efficiency of DMDS from all DES after $5 \mathrm{~h}$ is higher than $99.999 \%$. From $\mathrm{ChCl}: \mathrm{Ph}$, DMDS can be completely removed after $3 \mathrm{~h}$ (Figure 7).

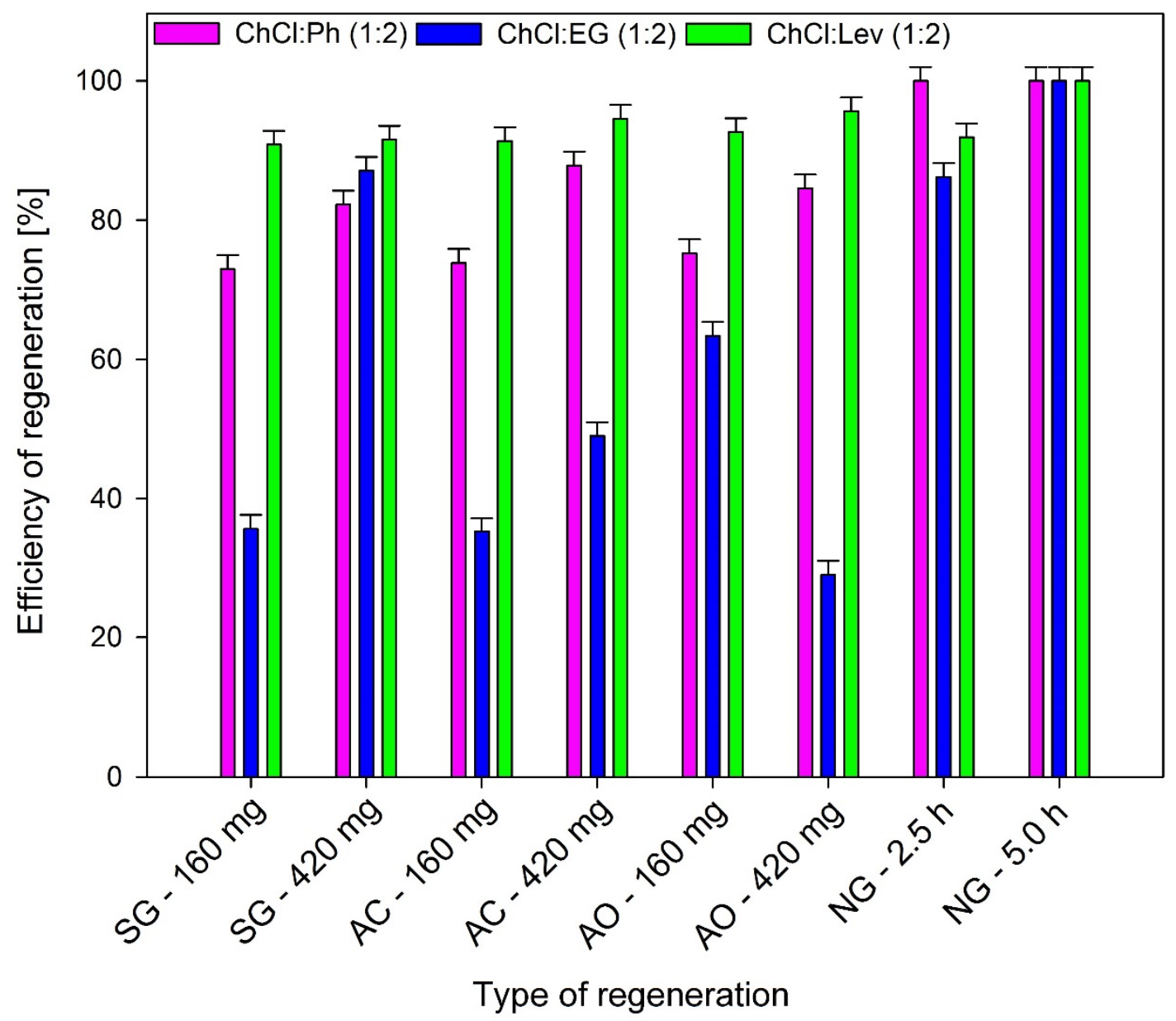

Figure 7. Regeneration efficiency of DESs after different regeneration methods.

For the remaining DES, this time should be extended, which would affect the cost of the process. In addition, the results show that slightly lower regeneration efficiencies for all DES were obtained

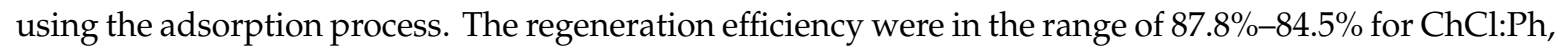
87.1\%-63.4\% for ChCl:EG, and 96.6\%-91.3\% ChCl:Lev. The highest absorption efficiency was obtained for $420 \mathrm{mg}$ of SG. In most cases, the increase in adsorbent mass relative to the amount of DES containing 
DMDS resulted in increased adsorption efficiency due to the increased adsorption surface. However, from an economical industrial point of view, the adsorbent amount should be as low as possible. Desorption is the most effective method to remove DMDS from ChCl:Lev. This is probably due to the low sorption capacity of $\mathrm{ChCl}$ :Lev and the absorption relatively small amount of DMDS.

The absorption-desorption results indicate that DMDS could be completely removed from DES and the absorbent could be reused for a minimum of five times without significant loss of absorption capacity DMDS (Figure 8a). In order to examine whether there were any structural changes in DES after the regeneration process (nitrogen barbotage), FT-IR analysis was used (Figure 8b-d). No additional peaks or shifts are observed in the DES spectra before and after regeneration, which indicates DES stability during the regeneration process.

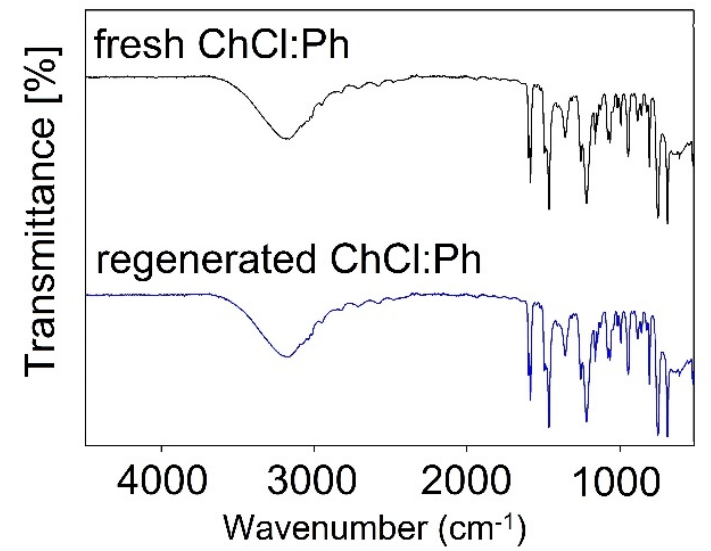

(a)

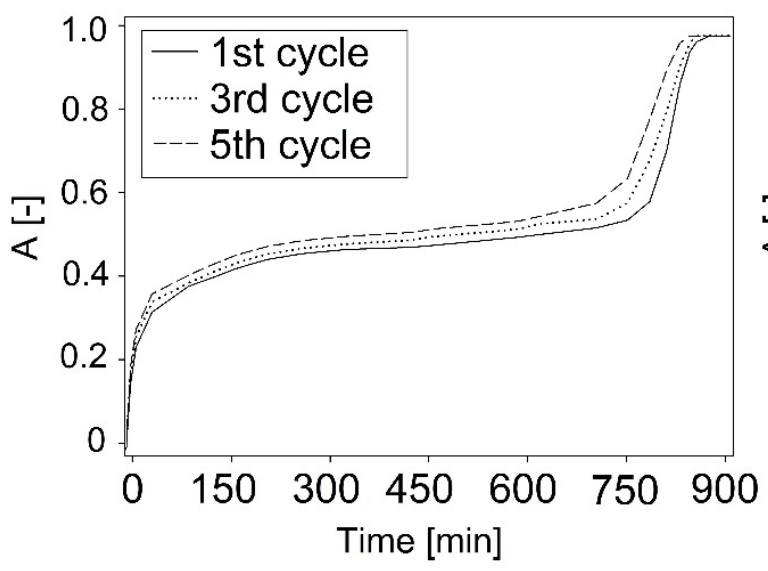

(c)

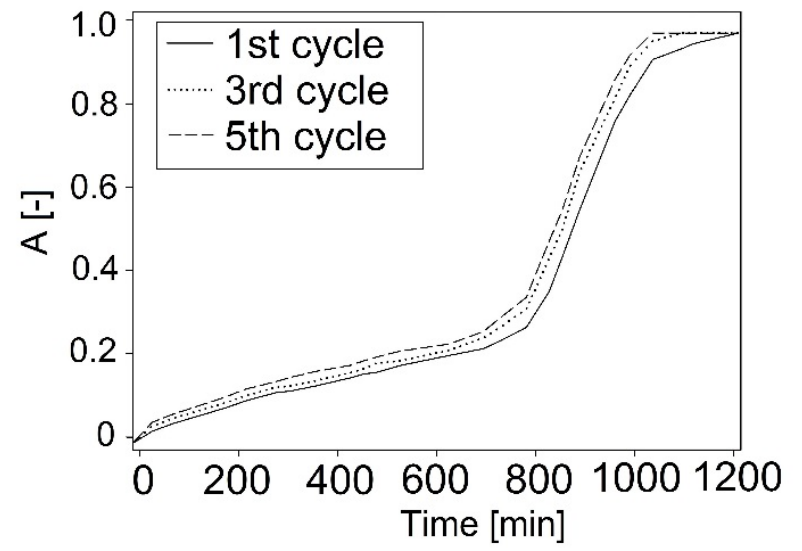

(b)

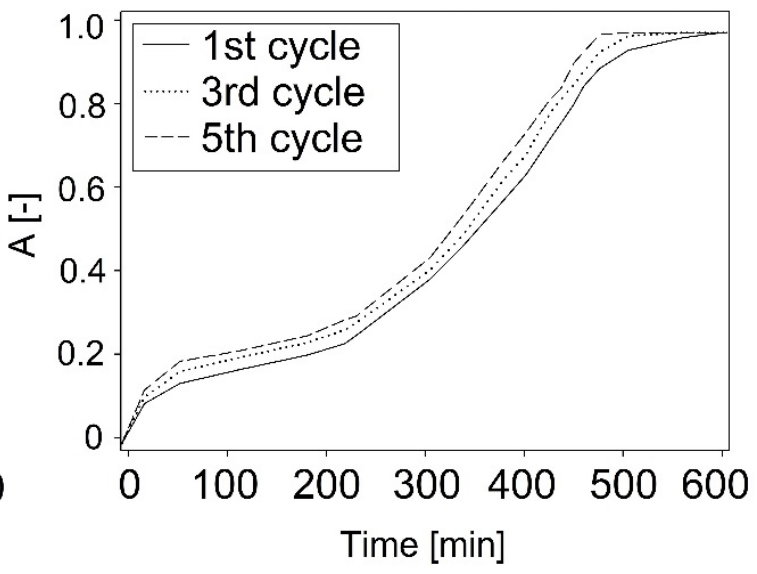

(d)

Figure 8. (a) FT-IR spectra recorded from on fresh $\mathrm{ChCl}: \mathrm{Ph}$, regenerated $\mathrm{ChCl}: \mathrm{Ph}$, and the reusability of DES: (b) ChCl:Ph; (c) ChCl:Lev; (d) ChCl:EG.

\section{Conclusions}

The choline chloride-based deep eutectic solvents have been synthesized and tested as alternative eco-friendly and green solvents for absorptive desulfurization of model biogas. Effect of selected absorption parameters including kind of DES, temperature, absorbent volume, model biogas flow rate, and initial concentration of DMDS were studied. It was found that the optimum absorption parameters for DMDS removal were absorption solvent $\mathrm{ChCl:Ph}$ in 1:2 molar ratio, $50 \mathrm{~mL}$ of DES, temperature $25^{\circ} \mathrm{C}$, and $50 \mathrm{~mL} / \mathrm{min}$ flow rate. The influence of DMDS concentration indicates that the initial amount of DMDS in model biogas has only a minor effect on the absorption capacity and rate. In the optimum conditions, DMDS was removed with high efficiency for $800 \mathrm{~min}$. After this time, the 
gradual saturation of DES occurred. After the absorption process, $\mathrm{ChCl:Ph}$ in 1:2 molar ratio could be regenerated by means of nitrogen barbotage and reuse without loss absorption capacity.

The studies on the absorptive desulfurization mechanism indicate that the van der Waals interaction is the main driving force for the efficient removal of DMDS from model biogas.

The developed absorption process with the choline chloride-based deep eutectic solvents provides a promising alternative method for the removal of volatile organosulfur compounds from the real biogas stream.

The paper presents preliminary results of research on the removal of DMDS from a model biogas stream. However, due to the rich composition of real biogas samples, other volatile organic compound groups should also be included in future studies. In addition, in the future, to verify the suitability of the developed method, the studies using real samples of heavily contaminated biogas streams from sewage treatment plants and landfills will be carried out.

Author Contributions: Writing—original draft preparation, E.S. and P.M.; writing—review and editing, E.S. and P.M.; conceptualization and methodology, E.S. and P.M.; experimental set-up and software, E.S. and P.M.; conducted the experiments and data curation, E.S. and P.M. All authors have read and agreed to the published version of the manuscript.

Funding: This research received no external funding.

Conflicts of Interest: The authors declare no conflicts of interest. The funders had no role in the design of the study; in the collection, analyses, or interpretation of data; in the writing of the manuscript, or in the decision to publish the results.

\section{References}

1. Guo, X.M.; Trably, E.; Latrille, E.; Carrre, H.; Steyer, J.P. Hydrogen production from agricultural waste by dark fermentation: A review. Int. J. Hydrogen Energy 2010, 35, 10660-10673. [CrossRef]

2. Słupek, E.; Makoś, P.; Kucharska, K.; Gębicki, J. Mesophilic and thermophilic dark fermentation course analysis using sensor matrices and chromatographic techniques. Chem. Pap. 2019, in press.

3. Bastidas-Oyanedel, J.R.; Bonk, F.; Thomsen, M.H.; Schmidt, J.E. Dark fermentation biorefinery in the present and future (bio)chemical industry. Rev. Environ. Sci. Biotechnol. 2015, 14, 473-498. [CrossRef]

4. Persson, M.; Jonsson, O.; Wellinger, A. Biogas Upgrading To Vehicle Fuel Standards and Grid; ISBN IEA Bioenergy Task 37; IEA Bioenergy: London, UK, 2007.

5. Andrés, C.; Guardia, A.D.; Couvert, A.; Wolbert, D.; Le, S.; Soutrel, I.; Nunes, G. Odor concentration $(\mathrm{OC})$ prediction based on odor activity values (OAVs) during composting of solid wastes and digestates. Atmos. Environ. 2019, 201, 1-12.

6. Papurello, D.; Soukoulis, C.; Schuhfried, E.; Cappellin, L.; Gasperi, F.; Silvestri, S.; Santarelli, M.; Biasioli, F. Monitoring of volatile compound emissions during dry anaerobic digestion of the Organic Fraction of Municipal Solid Waste by Proton Transfer Reaction Time-of-Flight Mass Spectrometry. Bioresour. Technol. 2012, 126, 254-265. [CrossRef] [PubMed]

7. Salazar Gómez, J.I.; Lohmann, H.; Krassowski, J. Determination of volatile organic compounds from biowaste and co-fermentation biogas plants by single-sorbent adsorption. Chemosphere 2016, 153, 48-57. [CrossRef]

8. Boczkaj, G.; Makoś, P.; Fernandes, A.; Przyjazny, A. New procedure for the control of the treatment of industrial effluents to remove volatile organosulfur compounds. J. Sep. Sci. 2016, 39. [CrossRef]

9. Makoś, P.; Boczkaj, G. Deep eutectic solvents based highly efficient extractive desulfurization of fuels-Eco-friendly approach. J. Mol. Liq. 2019, 111916. [CrossRef]

10. Andersson, F.A.T.; Karlsson, A.; Svensson, B.H.; Ejlertsson, J. Occurrence and abatement of volatile sulfur compounds during biogas production. J. Air Waste Manag. Assoc. 2004, 54, 855-861. [CrossRef]

11. Sarmad, S.; Mikkola, J.-P.; Ji, X. $\mathrm{CO}_{2}$ capture with Ionic liquids (ILs) and Deep Eutectic Solvents (DESs): A new generation of sorbents. ChemSusChem 2016, 10, 324-352. [CrossRef]

12. Sevimoğlu, O.; Tansel, B. Effect of persistent trace compounds in landfill gas on engine performance during energy recovery: A case study. Waste Manag. 2013, 33, 74-80. [CrossRef] [PubMed]

13. Sun, Q.; Li, H.; Yan, J.; Liu, L.; Yu, Z.; Yu, X. Selection of appropriate biogas upgrading technology-a review of biogas cleaning, upgrading and utilisation. Renew. Sustain. Energy Rev. 2015, 51, 521-532. [CrossRef] 
14. Allegue, L.B.; Hinge, J. Biogas upgrading Evaluation of methods for H 2 S removal. Dan. Technol. Inst. 2014, 31.

15. Mahmood, Q.; Zheng, P.; Cai, J.; Hayat, Y.; Hassan, M.J.; Wu, D.L.; Hu, B.L. Sources of sulfide in waste streams and current biotechnologies for its removal. J. Zhejiang Univ. Sci. A 2007, 8, 1126-1140. [CrossRef]

16. Burgess, J.E.; Parsons, S.A.; Stuetz, R.M. Developments in odour control and waste gas treatment biotechnology: A review. Biotechnol. Adv. 2001, 19, 35-63. [CrossRef]

17. Ryckebosch, E.; Drouillon, M.; Vervaeren, H. Techniques for transformation of biogas to biomethane. Biomass Bioenergy 2011, 35, 1633-1645. [CrossRef]

18. Nordlander, E.; Holgersson, J.; Thorin, E.; Thomassen, M.; Yan, J. Energy Efficiency Evaluation of two Biogas Plants. Int. Conf. Appl. Energy 2011, 1661-1675.

19. Rossi, F.; Nicolini, A. A cylindrical Small Size Molten Carbonate Fuel Cell: Experimental Investigation on Materials and Improving Performance Solutions. Fuel Cells 2009, 9, 170-177. [CrossRef]

20. Rossi, F. A new geometry high performance small power MCFC. J. Fuel Cell Sci. Technol. 2004, 1-6. [CrossRef]

21. Tippayawong, N.; Thanompongchart, P. Biogas quality upgrade by simultaneous removal of $\mathrm{CO}_{2}$ and $\mathrm{H}_{2} \mathrm{~S}$ in a packed column reactor. Energy 2010, 35, 4531-4535. [CrossRef]

22. Noorain, R.; Kindaichi, T.; Ozaki, N.; Aoi, Y.; Ohashi, A. Biogas purification performance of new water scrubber packed with sponge carriers. J. Clean. Prod. 2019, 214, 103-111. [CrossRef]

23. Farooq, M.; Chaudhry, I.A.; Hussain, S.; Ramzan, N.; Ahmed, M. Biogas Up Gradation for Power Generation Applications in Pakistan. J. Qual. Technol. Manag. Vol. Viiiissue Ii 2012, VIII, 107-118.

24. Wilk, A.; Więcław-Solny, L.; Tatarczuk, A.; Krótki, A.; Spietz, T.; Chwoła, T. Solvent selection for $\mathrm{CO}_{2}$ capture from gases with high carbon dioxide concentration. Korean J. Chem. Eng. 2017, 34, 2275-2283. [CrossRef]

25. Xu, H.J.; Zhang, C.F.; Zheng, Z.S. Solubility of hydrogen sulfide and carbon dioxide in a solution of methyldiethanolamine mixed with ethylene glycol. Ind. Eng. Chem. Res. 2002, 41, 6175-6180. [CrossRef]

26. Romero, A.; Santos, A.; Tojo, J.; Rodríguez, A. Toxicity and biodegradability of imidazolium ionic liquids. J. Hazard. Mater. 2008, 151, 268-273. [CrossRef] [PubMed]

27. Makoś, P.; Słupek, E.; Gębicki, J. Hydrophobic deep eutectic solvents in microextraction techniques-A review. Microchem. J. 2020, 152, 104384. [CrossRef]

28. Zhang, Q.; De Oliveira Vigier, K.; Royer, S.; Jérôme, F. Deep eutectic solvents: Syntheses, properties and applications. Chem. Soc. Rev. 2012, 41, 7108-7146. [CrossRef]

29. Smink, D.; Kersten, S.R.A.; Schuur, B. Recovery of lignin from deep eutectic solvents by liquid-liquid extraction. Sep. Purif. Technol. 2019, 235, 116127. [CrossRef]

30. Florindo, C.; Branco, L.C.; Marrucho, I.M. Development of hydrophobic deep eutectic solvents for extraction of pesticides from aqueous environments. Fluid Phase Equilibria 2017, 448, 135-142. [CrossRef]

31. Zubeir, L.F.; Van Osch, D.J.G.P.; Rocha, M.A.A.; Banat, F.; Kroon, M.C. Carbon Dioxide Solubilities in Decanoic Acid-Based Hydrophobic Deep Eutectic Solvents. J. Chem. Eng. Data 2018, 63, 913-919. [CrossRef]

32. Pätzold, M.; Siebenhaller, S.; Kara, S.; Liese, A.; Syldatk, C.; Holtmann, D. Deep Eutectic Solvents as Efficient Solvents in Biocatalysis. Trends Biotechnol. 2019, 37, 943-959. [CrossRef] [PubMed]

33. Makoś, P.; Fernandes, A.; Przyjazny, A.; Boczkaj, G. Sample preparation procedure using extraction and derivatization of carboxylic acids from aqueous samples by means of deep eutectic solvents for gas chromatographic-mass spectrometric analysis. J. Chromatogr. A 2018, 1555, 10-19. [CrossRef] [PubMed]

34. Makoś, P.; Przyjazny, A.; Boczkaj, G. Hydrophobic deep eutectic solvents as "green" extraction media for polycyclic aromatic hydrocarbons in aqueous samples. J. Chromatogr. A 2018, 1570, 28-37. [CrossRef] [PubMed]

35. Sun, S.; Niu, Y.; Xu, Q.; Sun, Z.; Wei, X. Efficient $\mathrm{SO}_{2}$ absorptions by four kinds of deep eutectic solvents based on choline chloride. Ind. Eng. Chem. Res. 2015, 54, 8019-8024. [CrossRef]

36. Yang, D.; Han, Y.; Qi, H.; Wang, Y.; Dai, S. Efficient Absorption of $\mathrm{SO}_{2}$ by EmimCl-EG Deep Eutectic Solvents. ACS Sustain. Chem. Eng. 2017, 5, 6382-6386. [CrossRef]

37. Florindo, C.; Lima, F; Branco, L.C.; Marrucho, I.M. Hydrophobic Deep Eutectic Solvents: A Circular Approach to Purify Water Contaminated with Ciprofloxacin. ACS Sustain. Chem. Eng. 2019, 7, 14739-14746. [CrossRef]

38. Moura, L.; Moufawad, T.; Ferreira, M.; Bricout, H.; Tilloy, S.; Monflier, E.; Costa Gomes, M.F.; Landy, D.; Fourmentin, S. Deep eutectic solvents as green absorbents of volatile organic pollutants. Environ. Chem. Lett. 2017, 15, 747-753. [CrossRef] 
39. Słupek, E.; Makoś, P.; Gȩbicki, J.; Rogala, A. Purification of model biogas from toluene using deep eutectic solvents. E3s Web Conf. 2019, 116, 00078.

40. Ma, Y.; Wang, Q.; Zhu, T. Comparison of hydrophilic and hydrophobic deep eutectic solvents for pretreatment determination of sulfonamides from aqueous environments. Anal. Methods 2019, 11, 5901-5909. [CrossRef]

41. Florindo, C.; Oliveira, F.S.; Rebelo, L.P.N.; Fernandes, A.M.; Marrucho, I.M. Insights into the synthesis and properties of deep eutectic solvents based on cholinium chloride and carboxylic acids. ACS Sustain. Chem. Eng. 2014, 2, 2416-2425. [CrossRef]

42. Kalhor, P.; Ghandi, K. Deep eutectic solvents for pretreatment, extraction, and catalysis of biomass and food waste. Molecules 2019, 24, 4012. [CrossRef] [PubMed]

43. Simon, S.; Duran, M.; Dannenberg, J.J. How does basis set superposition error change the potential surfaces for hydrogen-bonded dimers? J. Chem. Phys. 1996, 105, 11024-11031. [CrossRef]

44. Johnson, E.R.; Keinan, S.; Mori-Sánchez, P.; Contreras-García, J.; Cohen, A.J.; Yang, W. Revealing noncovalent interactions. J. Am. Chem. Soc. 2010, 132, 6498-6506. [CrossRef] [PubMed]

45. Lu, T.; Chen, F. Quantitative analysis of molecular surface based on improved Marching Tetrahedra algorithm. J. Mol. Graph. Model. 2012, 38, 314-323. [CrossRef] [PubMed]

46. Lu, T.; Chen, F. Multiwfn: A multifunctional wavefunction analyzer. J. Comput. Chem. 2012, 33, 580-592. [CrossRef] [PubMed]

47. Noyola, A.; Morgan-sagastume, J.M.; Lo, J.E.; Ingenierı, I.D.; Escolar, C.; Universitaria, C.; Me, D.F. Treatment of biogas produced in anaerobic reactors for domestic wastewater: Odor control and energy/resource recovery. Rev. Environ. Sci. Bio. Technol. 2006, 51, 93-114. [CrossRef]

48. Ducom, G.; Radu-tirnoveanu, D.; Pascual, C.; Benadda, B.; Germain, P. Biogas-Municipal solid waste incinerator bottom ash interactions: Sulphur compounds removal. J. Hazard. Mater. 2009, 166, 1102-1108. [CrossRef]

49. Arespacochaga, N.D.; Valderrama, C.; Mesa, C.; Bouchy, L.; Cortina, J.L. Biogas deep clean-up based on adsorption technologies for Solid Oxide Fuel Cell applications. Chem. Eng. J. 2020, 255, 593-603. [CrossRef]

50. Privalova, E.; Rasi, S.; Mäki-Arvela, P.; Eränen, K.; Rintala, J.; Murzin, D.Y.; Mikkola, J.P. CO 2 capture from biogas: Absorbent selection. RSC Adv. 2013, 3, 2979-2994. [CrossRef]

51. Hsu, C.H.; Chu, H.; Cho, C.M. Absorption and reaction kinetics of amines and ammonia solutions with carbon dioxide in flue gas. J. Air Waste Manag. Assoc. 2003, 53, 246-252. [CrossRef]

52. Guo, Y.; Niu, Z.; Lin, W. Comparison of removal efficiencies of carbon dioxide between aqueous ammonia and $\mathrm{NaOH}$ solution in a fine spray column. Energy Procedia 2011, 4, 512-518.

53. Gonzalez-Garza, D.; Rivera-Tinoco, R.; Bouallou, C. Comparison of ammonia, monoethanolamine, diethanolamine and methyldiethanolamine solvents to reduce $\mathrm{CO}_{2}$ greenhouse gas emissions. Chem. Eng. Trans. 2009, 18, 279-284.

54. Zhang, K.; Ren, S.; Yang, X.; Hou, Y.; Wu, W.; Bao, Y. Efficient absorption of low-concentration $\mathrm{SO}_{2}$ in simulated flue gas by functional deep eutectic solvents based on imidazole and its derivatives. Chem. Eng. J. 2017, 327, 128-134. [CrossRef]

55. Lemus, J.; Bedia, J.; Moya, C.; Alonso-Morales, N.; Gilarranz, M.A.; Palomar, J.; Rodriguez, J.J. Ammonia capture from the gas phase by encapsulated ionic liquids (ENILs). RSC Adv. 2016, 6, 61650-61660. [CrossRef]

56. Meyer, M. Infrared, raman, microwave and ab initio study of dimethyl disulfide: Structure and force field. J. Mol. Struct. 1992, 273, 99-121. [CrossRef]

57. Biswal, H.S.; Chakraborty, S.; Wategaonkar, S. Experimental evidence of O-H-S hydrogen bonding in supersonic jet. J. Chem. Phys. 2008, 129. [CrossRef]

58. Biswal, H.S.; Wategaonkar, S. Sulfur, not too far behind O, N, and C: SH $\cdots \pi$ hydrogen bond. J. Phys. Chem. A 2009, 113, 12774-12782. [CrossRef]

59. Bhattacharyya, S.; Bhattacherjee, A.; Shirhatti, P.R.; Wategaonkar, S. O-H $\cdots$ S hydrogen bonds conform to the acid-base formalism. J. Phys. Chem. A 2013, 117, 8238-8250. [CrossRef]

60. Minch, M.J. An Introduction to Hydrogen Bonding (Jeffrey, George A.). J. Chem. Educ. 1999, 76, 759. [CrossRef]

(C) 2020 by the authors. Licensee MDPI, Basel, Switzerland. This article is an open access article distributed under the terms and conditions of the Creative Commons Attribution (CC BY) license (http://creativecommons.org/licenses/by/4.0/). 